\title{
Małgorzata Marcysiak, Kształtowanie się pielęgniarstwa społecznego jako działu medycyny społecznej na przykładzie województwa Iwowskiego w latach 1929-1939, Instytut Historii Nauki im. Ludwika i Aleksandra Birkenmajerów Polskiej Akademii Nauk, Warszawa 2018, ss. 336 (rec. Katarzyna Trzęsiel)
}

Kształtowanie sie pielęgniarstwa społecznego jako działu medycyny społecznej na przykładzie województwa lwowskiego w latach 1929-1939 jest monografią autorstwa Małgorzaty Marcysiak, napisaną pod opieką naukową prof. Bożeny Urbanek, a recenzowaną przez prof. Elżbietę Krajewską-Kułak i prof. Andrzeja Felchnera. Z 336 stron 16 stanowi bibliografia, co świadczy o licznych źródłach cytowań oraz skrupulatności w opracowaniu publikacji. Przygotowując pracę, Autorka gruntowną kwerendą objęła materiały źródłowe. Zweryfikowała treść czasopism polskich medycznych i społecznych zarówno o zasięgu krajowym, jak i lokalnym. Wśród nich: „Pielęgniarka Polska”, „Zdrowie”, „Zdrowie Publiczne”, „Polski Czerwony Krzyż”, „Opieka nad Matką i Dzieckiem”, „Położna” oraz „Opiekun Społeczny”. Dokonała również analizy czasopism naukowych, ogólnolekarskich, w tym m.in.: „Polska Gazeta Lekarska”, „Lekarz Polski” i „Nowiny Społeczno-Lekarskie”. Zamieszczone w nich artykuły pozwoliły jej dość obiektywnie ocenić omawiane zagadnienie. Rzetelność opisu potwierdzają archiwalia: sprawozdania, dokumenty, pisma urzędowe, statuty, regulaminy i program nauczania, znajdujące się w Archiwum Akt Nowych w Warszawie, w zbiorach Ossolińskich we Wrocławiu w Dziale Dokumentów Życia Społecznego, jak również w zbiorach specjalnych Głównej Biblioteki Lekarskiej w Warszawie. Uzupełnienie wymienionych źródeł stanowią pamiętniki i wspomnienia pielęgniarek społecznych pracujących w badanym terenie, dostępne w Centralnym Archiwum Pielęgniarstwa Polskiego im. Barbary Purtak w Warszawie. W publikacji odniesiono się również do opracowań opartych na archiwaliach zgromadzonych w Państwowym Archiwum Obwodu Lwowskiego oraz do relacji ustnych żyjących świadków ówczesnych zdarzeń, szczególnie pielęgniarek. Autorka wspomina także o trudnościach, które napotkała podczas gromadzenia i analizy materiałów, w szczególności dotyczących pozyskania źródeł znajdujących się we lwowskich archiwach. Zamieszczone w książce tabele, ryciny oraz aneksy wzbogacają dzieło pod względem naukowym i meryto- 
rycznym. M. Marcysiak wykonała drobiazgową i czasochłonną analizę, która zaowocowała solidną bazą informacyjną. Rozprawa ukazuje proces poznania okoliczności kształtowania się pielęgniarstwa społecznego jako działu medycyny społecznej z uwzględnieniem realiów województwa lwowskiego w dwudziestoleciu międzywojennym. W książce można także zauważyć, co istotne, próbę oceny wspomnianej sytuacji.

Monografia składa się z sześciu rozdziałów poprzedzonych wstępem. Stanowi ona pierwsze opracowanie dotyczące kształtowania się pielęgniarstwa społecznego $\mathrm{w}$ województwie lwowskim $\mathrm{w}$ okresie międzywojennym. Prezentuje krótki zarys historyczny o specyficznym rodzaju pracy pielęgniarki w zakresie zdrowia publicznego, podkreślając jej znaczenie z uwagi na niepokojący stan zdrowotny społeczeństwa polskiego $\mathrm{w}$ tym czasie.

We wprowadzeniu Autorka określa cel swojej monografii, którym było uzyskanie odpowiedzi na postawione poniżej pytania badawcze:

1. Czy uregulowania prawne i wynikająca z nich struktura organizacyjna służby zdrowia były reakcją na sytuację epidemiologiczną w okresie międzywojennym?

2. Jakie kierunki działania wyznaczała medycyna społeczna?

3. W jaki sposób specyfika geograficzno-demograficzna, sanitarno-epidemiologiczna i społeczno-zdrowotna województwa lwowskiego warunkowała rozwój pielęgniarstwa społecznego?

4. Czy pielęgniarki społeczne były przygotowane do pełnienia zadań w dziedzinie medycyny społecznej?

5. Czy ośrodek zdrowia jako instytucja zdrowia publicznego stanowił właściwe miejsce do realizacji zadań pielęgniarstwa społecznego?

6. Jak wyglądała praca pielęgniarek społecznych w rzeczywistości województwa lwowskiego $\mathrm{z}$ uwzględnieniem różnic między miastem a wsią i co było wskaźnikiem efektywności ich pracy?

Autorka, pisząc publikację, zastosowała metodę badania dokumentów. Skupiła się na analizie i krytyce piśmiennictwa oraz dokonała weryfikacji danych liczbowych i ich statystycznego uporządkowania. Monografia, jak już wspomniano, zawiera sześć zasadniczych rozdziałów opatrzonych tytułami. Każdy z nich składa się z kilku części, nadając przejrzystą konstrukcję pracy.

Rozdział pierwszy stanowi zwartą tematycznie strukturę, w której Autorka prezentuje dwie koncepcje dotyczące organizacji i kompetencji organu, który miał się zająć sprawami zdrowia publicznego. Pierwsza z nich zakładała zdecentralizowanie administracji służby 
zdrowia przez podporządkowanie jej administracji samorządowej i utworzenie samodzielnego ministerstwa zdrowia publicznego. Druga zaś zakładała konieczność skoordynowania działań na rzecz zdrowia obywateli oraz możliwość kompleksowego, jednolitego systemu zarządzania sprawami zdrowia. Ponadto M. Marcysiak zwraca uwagę na brak odpowiednich do potrzeb uregulowań prawnych, które utrudniały organizację aparatu służby zdrowia. Przytacza dwa podstawowe akty prawne z 1919 r., które wymagały nowelizacji. W okresie międzywojennym opracowano szereg niezbędnych przepisów prawnych, były to rozporządzenia, ustawy, instrukcje, szczegółowe, choć i fragmentaryczne przepisy normujące kwestię zapobiegania chorobom społecznym, jak np. gruźlica czy jaglica. Wieloletnie prace zakończyły się jednak zaledwie złożeniem projektu. $Z$ kolei ustawa o publicznej służbie zdrowia z 1939 roku co prawda porządkowała stan prawny lecznictwa samorządowego, precyzowała zadania publicznej służby zdrowia, ale nie wpłynęła na sytuację zdrowotną społeczeństwa, ponieważ nie została wdrożona w życie z uwagi na wybuch II wojny światowej. Nieuregulowana kwestia zdrowia publicznego przekładała się na poszczególne regiony, szczególnie na województwo lwowskie. Obok trudności organizacyjnych pojawiły się braki personalne i przeszkody ekonomiczne. Kształtujące się $\mathrm{w}$ tym rejonie pielęgniarstwo napotykało na wiele przeszkód. W celu usprawnienia systemu opieki w administracji państwowej w 1926 r. utworzono w Departamencie Służby Zdrowia Referat Pielęgniarski. Umożliwiało to bezpośredni nadzór i rozpoznanie rzeczywistych potrzeb.

W rozdziale drugim Autorka prezentuje nadrzędne kierunki medycyny społecznej w kraju. Pisze także o wpływie warunków środowiskowych na zdrowie populacji. Wyjaśnia pojęcia z zakresu medycyny społecznej, takie jak: medycyna społeczna, higiena, zdrowie publiczne i pielęgniarstwo społeczne. Badaczka ukazuje w tym rozdziale, że ochrona zdrowia miała być zadaniem priorytetowym w okresie międzywojennym zarówno dla władz państwowych, samorządowych, jak i dla organizacji społecznych. Przedstawia dwa główne nurty w rozwoju medycyny społecznej, które wpłynęły na jej ukształtowanie. Pierwszy polegał na włączeniu do obszarów medycznych problematyki środowiskowej obejmującej warunki bytowania i pracy człowieka oraz ukazywaniu przyczyn najczęstszych chorób, tkwiących w trudnościach ekonomicznych i zaniedbaniach higienicznych. Drugi miał na celu działania na rzecz upowszechniania opieki lekarskiej i zwiększenie możliwości zapewniania pomocy w chorobie dla różnych warstw 
społecznych. Autorka wspomina również o szczególnej roli ośrodków zdrowia w medycynie społecznej, głównie kierowanych do ubogiej lokalnej społeczności. To w nich pielęgniarki społeczne pełniły funkcję profilaktyczną, pielęgnacyjną i edukacyjno-wychowawczą. Dlatego też M. Marcysiak poświęciła szczególną uwagę podrozdziałowi dotyczącemu kwalifikacji pielęgniarek. Przedstawiła fachowe przygotowanie pielęgniarek społecznych do pełnienia tych zadań, podkreśliła, iż ta dziedzina wymagała szczególnego, profesjonalnego przygotowania, a zatem wysokich kwalifikacji, dając zarazem pielęgniarkom szeroki zakres kompetencji.

W kolejnym rozdziale Autorka omówiła sytuację zdrowotną społeczeństwa w województwie lwowskim wynikającą ze specyfiki sytuacji demograficznej, sanitarnej, epidemiologicznej, ekonomicznej, kulturowej i narodowościowej. Na postawie własnych opracowań oraz analizy dostępnych źródeł przedstawiła, w postaci tabel i wykresów, warunki geograficzno-demograficzne, sytuację sanitarno-epidemiologiczną oraz uwarunkowania społeczno-zdrowotne w województwie lwowskim. Wszystkie czynniki składające się na analizę struktury demograficznej, społecznej, sanitarnej i epidemiologicznej ukazały nierówne szanse społeczeństwa w dostępie do służby zdrowia. Autorka zauważa negatywny wpływ niskiej świadomości zdrowotnej i sanitarno-higienicznej społeczeństwa, co ograniczało korzystanie z proponowanych działań na rzecz zdrowia i higieny. M. Marcysiak ukazała niekorzystny obraz warunków województwa lwowskiego. Na uwagę zasługuje obszerny aneks do rozdziału, który prezentuje omawiane treści.

W rozdziale czwartym Autorka publikacji koncentruje się na szczególnych predyspozycjach i umiejętnościach pielęgniarek społecznych. Ukazany został proces kształcenia, podczas którego pielęgniarki były przygotowywane do pełnienia zadań zgodnie z założeniami medycyny społecznej. W jednym z podrozdziałów badaczka opisuje specyfikę lwowskiej szkoły, prezentuje program kształcenia oraz formułe egzaminu końcowego. Autorka słusznie zauważa, że szkoła niewystarczająco przygotowywała pielęgniarki społeczne do wykonywanych zadań zarówno w zakresie teorii, jak i praktyki. Trudna sytuacja środowiskowa wymagała specjalistycznego przygotowania. Dlatego też kierowano pielęgniarki na seminaria oraz kursy doszkalające nie tylko w Polsce, ale także poza jej granicami, gdzie mogły uzupełnić wiedzę. Dzięki podejmowanym działaniom wzrastały kwalifikacje pielęgniarek społecznych w dziedzinie zdrowia publicznego. M. Mar- 
cysiak wskazuje na potrzebne do tego zawodu predyspozycje fizyczne, psychiczne i moralne. W realiach województwa lwowskiego praca ta, głównie na wsi, była niezwykle trudna. Autorka podkreśla, że okres międzywojenny wymagał od pielęgniarek społecznych wysokich kwalifikacji i umiejętności odnalezienia się w środowisku pacjenta.

Kolejny rozdział traktuje o genezie placówek zdrowia publicznego. Autorka zwraca szczególną uwagę na ośrodki zdrowia, które były właściwym miejscem do realizacji zadań pielęgniarek społecznych. Opisuje ich strukturę organizacyjną, rolę i zadania, wymagania względem personelu medycznego oraz źródła finansowania. M. Marcysiak, analizując źródła, ukazuje w przejrzysty sposób rozwój ośrodków zdrowia we Lwowie i województwie lwowskim w poszczególnych latach. Wykorzystuje w tym celu tabele i mapy, co czyni treści jasnymi w odczycie. Wspomina, że początkowo funkcjonowały przychodnie, organizacje i instytucje społeczne, państwowe, a nawet prywatne.

W ostatnim rozdziale książki Autorka szeroko omawia funkcjonowanie pielęgniarstwa społecznego w województwie lwowskim w okresie międzywojennym. Na kolejnych kartach publikacji można dostrzec wyniki szczegółowej analizy danych dotyczących rozwoju kadr we Lwowie i powiecie lwowskim. Autorka przedstawia dynamiczny rozwój kadr pielęgniarskich oraz intensywny wzrost fachowego personelu. Ze starannością mówi o bardzo ważnej roli pielęgniarki społecznej, wskazując na odrębność zadań w mieście i na prowincji. Zauważa też, że pielęgniarki nie były zupełnie samodzielne w podejmowanych działaniach, ponieważ miały obok siebie lekarzy, którzy niejednokrotnie obawiali się konkurencji z ich strony. Co bardzo istotne, Autorka, kończąc swoją monografię, prezentuje szeroką gamę efektów pracy pielęgniarek społecznych $\mathrm{w}$ województwie lwowskim. Trafnie zauważa, że obecność pielęgniarek społecznych w środowisku niewątpliwe przyczyniła się do podniesienia poziomu świadomości w zakresie postrzegania zasad higieny osobistej i otoczenia. Jako efekty pracy pielęgniarek społecznych Autorka wskazuje zmniejszenie zachorowalności na choroby społeczne, poprawę stanu zdrowia osób starszych, a także zmniejszenie zachorowalności i umieralności niemowląt. Małgorzata Marcysiak zwraca jednocześnie uwagę na zbyt wolno następujące zmiany, które wynikały z sytuacji ekonomicznej kraju.

Publikację kończy podsumowanie, w którym Autorka formułuje wnioski dotyczące założeń medycyny społecznej oraz kształtowania się i rozwoju dziedziny pielęgniarstwa społecznego w województwie lwowskim $\mathrm{w}$ okresie międzywojennym. Jednym $\mathrm{z}$ atutów książki 
M. Marcysiak jest jej oryginalny charakter, dzięki czemu podjęte zagadnienie pielęgniarstwa społecznego nie tylko zostało szczegółowo zaprezentowane, ale także staje się wstępem do dalszych badań w tej kwestii. Monografia stanowi bardzo cenną pozycję na polskim rynku wydawniczym dla wszystkich osób zajmujących się lub interesujących rozwojem pielęgniarstwa społecznego jako działu medycyny społecznej. Jest to inspirująca lektura, posiadająca walory poznawcze i dydaktyczne, której niewątpliwą zaletą jest również to, że może po nią sięgnąć profesjonalista zajmujący się medycyną, jak i szersze grono czytelników. 